\section{TÀI LIÊU THAM KHẢO}

1. Phạm Đức Huấn, Đỗ Đức Vân (2000). Phẫu thuật cắt ung thư thực quản kinh nghiệm kết quả 71 trường hợp, Ngoại khoa số 3, Tr 22-25.

2. Lâm Việt Trung, Nguyễn Minh Hải, Võ Tấn Long và cộng sự (2012). Đánh giá tính khả thi, an toàn và kết quả ngắn hạn trong phẫu thuật nội soi điêu trị UTTO,Phấu thuât nối soi tâp 2, số 1, Tr 48-52.

3. Triệu Triêu Dương (2008). Nghiên cứu phẩu thuật nội soi điều trị UTTQ tại bệnh viện $108^{\prime \prime}$. Y hoc TP. Hồ Chí Minh, 12, Tr 200-203.

4. Luketich J. D., Pennathur A., AwaisO., Levy R. M., Keeley s., ShendeM., et al. (2012),
Outcomes after minimally invasive esophagectomy: review ofover 1000 patients. Ann Surg, 256(1), 95-103.

5. Atkins B. Z., Shah A. S., Hutcheson K. A., et al (2004), Reducing hospital morbidity and mortality following esophagectomy. Ann Thorac Surg, 78(4), 1170- 1176; discussion 1170-1176.

6. Bakhos C. T., Fabian T., Oyasiji T. O., et al (2012), Impact of the surgical technique on pulmonary morbidity after esophagectomy. Ann Thorac Surg, 93(1), 221-226; discussion 226-227.

7. Ferri L. E., Law S., Wong K. H., et al (2006), The influence of technical complications on postoperative outcome and survival after esophagectomy. Ann Surg Oncol, 13(4), 557-564

\title{
CÁC KÍCH THƯớC TỪ CÁC VÁCH XƯƠNG VÙNG CHÓP ĐẾN CÁC CẤU TRÚC GIẢI PHẪU CỦA RĂNG CỐI LỚN THỨ NHẤT HÀM DƯỚI TRÊN CONEBEAM CT
}

\author{
Đống Thị Kim Uyên ${ }^{1}$, Phạm Văn Khoa ${ }^{1}$, Huỳnh Kim Khang ${ }^{1}$
}

\section{TÓM TẮT}

Mục tiêu: Xác định các kích thước từ vách xương ngoài, trong đến vị trí cách chóp $3 \mathrm{~mm}$ của mỗi chân răng và bề rộng xương hàm dưới tại vị trí này ở vùng răng cối lớn thứ nhất hàm dưới ở người Việt Nam Phương pháp: Nghiên cứu được thực hiện trên 166 bệnh nhân chụp phim CBCT theo chỉ định của bác sĩ tại Trung tâm CT nha khoa Nguyễn Trãi, Thành Phố Hồ Chí Minh, trong thời gian nghiên cứu từ tháng 10/2015 đến tháng 6/2016. Phim CBCT được chụp bằng máy chụp phim Picasso Trio (Ewoo Vatech, Korea) với các điều kiện và tư thế chuẩn của bệnh nhân cho chụp phim. Hình ảnh CÕBCT thu thập từ trung tâm CT đạt tiêu chuẩn chọn mấu được quan sát trên máy tính màn hình phẳng 14 inches, độ phân giải 1366 x 768 pixel với phần mềm EzImplant CD viewer. Ghi nhận vị trí răng (răng 36 và răng 46), phim cần đo được chuyển về chế độ xem gốc ban đâu (thao tác Reset all), với độ phóng đại 1,5 lần. Trong mă̆t phẳng ngang (Áxial) di chuyển gốc trục tọa độ đển chính giữa mối chân răng của răng cối lớn thứ nhất hàm dưới cần đo, đường cắt đứng dọc theo hướng ngoài trong, chia chân răng thành hai phần tương đối bằng nhau. Trong mătt phẳng đứng dọc (Sagittal) điều chỉnh đường cắt đứng dọc theo trục môi chân răng cần đo. Tiến hành vẽ và đo đạc trong mặt phẳng đứng ngang (Coronal) (độphóng đại 2 lần). Xác định các kích thước tại vị trí mỗi chân răng. Kết quả: Đối với các $\mathrm{RCL}$ thứ nhất hàm dưới có hai chân, khoảng cách từ mặt ngoài XHD đến chóp chân gần và chân xa

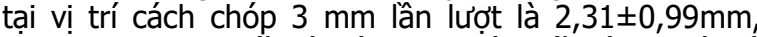
$3,22 \pm 1,77 \mathrm{~mm}$. Đối với các $\mathrm{RCL}$ thứ nhất hàm dưới có

${ }^{1}$ Đại học Y Dướ TP.HCM

Chịu trách nhiệm chính: Huỳnh Kim Khang

Email: kimkhanghuynh@yahoo.com

Ngày nhận bài: 12/9/2021

Ngày phản biên khoa học: 3/10/2021

Ngày duyệt bài: $21 / 10 / 2021$ ba chân, khoảng cách từ mặt ngoài XHD đến chóp chân gần và chân xa ngoài và chân xa trong tại vị trí

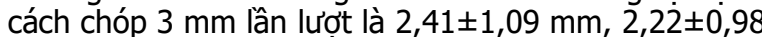
mm, 8,66士1,23 mm. Kết luận: Chóp các chân răng của RCL thứ nhất hàm dưới nằm rất gần mặt ngoài xương hàm dưới, lưu ý các bác sĩ phẫu thuật nội nha cẩn trọng trong các thủ thuật điều trị phấu thuật nội nha cho các răng này.

Tư khóa: khoảng cách, vách xương vùng chóp, răng cối lớn thứ nhất hàm dưới, ConeBeam CT

Các từ viết tắt: RCL: răng cối lớn; $B N$ : bệnh nhân; KC: khoảng cách, XHD: xương hàm dưới

\section{SUMMARY \\ DIMENSIONS FROM APICAL BONE WALLS TO ANATOMIC STRUCTURES OF THE FIRST LOWER MOLARS ON CONEBEAM CT \\ Objectives: The aim of the study is to determine} the distances from outer and inner of bone walls to the position $3 \mathrm{~mm}$ from the apices and the width of lower bone at this position of the first lower molars in Vietnamese on ConeBeam CT. Methods: The study was conducted on 166 patients who had exposured using CBCT indicated by dentists in Nguyen Trai Dental CT Central, HoChiMinh City, from October 2015 to June 2016. The CBCT digital images were captures using Picasso Trio (Ewoo Vatech, Korea) with the standard conditions and postures of patients. CBCT digital images were displayed on the 14 inches flat monitor, at $1366 \times 768$ pixel resolution with EzImplant $C D$ viewer software. The positions of the first lower molars were recorded. The images needed measured were converted to the original status (reset all action) with the magnification of 1.5 times. In the axial plane, the origin of coordinate axis was moved to the middle of each root of the first lower molars, so that the sagittal section line following buccal-lingual direction divided the root into relative same two parts. In the sagittal plane, the sagittal section line was adjusted following the axis of each root. In the coronal plane, 
some lines were drew and the dimensions were measured. Results: For the first lower molars with two roots, the distances from outer of lower bone to the mesial and distal apices at the position $3 \mathrm{~mm}$ from the apex were $2.31 \pm 0.99 \mathrm{~mm}, 3.22 \pm 1.77 \mathrm{~mm}$, respectively. For the first lower molars with three roots, the distances from outer of lower bone to the mesial, distal-buccal and distal-lingual apices were $2.41 \pm 1.09 \mathrm{~mm}, 2.22 \pm 0.98 \mathrm{~mm}$ and $8.66 \pm 1.23 \mathrm{~mm}$ respectively. Conclusion: Apecies of the mandibular first molars were located so near to the outer of lower jaw, this raised the notifications for the surgeon in endodontic surgery for these molars.

Key words: Distance, apical bone wall, first lower molar, ConeBeam CT.

\section{I. ĐẶT VẤN ĐỀ}

Trong bộ răng con người, răng cối lớn thứ nhất hàm dưới là một trong những răng vĩnh viễn đầu tiên mọc lên trong miệng, vào khoảng sáu tuổi, đánh dấu sư khởi đầu của bộ răng hỗn hợp. Răng cối lớn thứ nhất hàm dưới mang đặc điểm cơ bản đặc trưng của các răng cối lớn, có vai trò quan trong trong viêc nhai nghiền thức ăn và giữ kích thước tâng dưới mặt.

Răng có tỉ lệ sâu mất trám cao nhất trên lâm sàng chính là rắng cối lớn thứ nhất hàm dưới, kể cả ở lứa tuổi còn trẻ. Do đó, những hiểu biết về hình thái chân răng, số lượng và vị trí ống tủy là rất quan trọng và cần thiết trong quá trình điều trị nha khoa như điều trị nội nha, phẫu thuật cắt chóp, nhổ răng. Răng cối lớn thứ nhất hàm dưới có hình thái chân răng và ống tủy khá phức tạp, đa số có hai chân răng và ba ống tủy. Răng thường được điêu trị nội nha nhiêu nhất là răng cối lớn thứ nhất hàm dưới, vì đây là răng vĩnh viễn mọc đâu tiên trên cung hàm và có hệ thống ống tủy phức tạp và cũng là răng có chức năng ăn nhai quan trọng cần được bảo tồn nhất.

Phẫu thuật nội nha cho các răng cối trên cung hàm mà đặc biệt là các răng cối lớn hàm dưới là một trong những thủ thuật có nhiều thách thức nhất đối với bác sĩ răng hàm mặt. Không những vì lý do khó tiếp cận do vùng giải phẫu đặc thù này, mà cấu trúc nhiều chân răng của răng cối lớn hàm dưới cũng là một trong những khó khăn khó vượt qua đối với những phẫu thuật viên còn thiếu kinh nghiệm.

Do đó, việc nghiên cứu về khoảng cách từ mặt ngoài xướng hàm dưới đến chân răng ở vị trí cách chóp $3 \mathrm{~mm}$ ở vùng răng cối lớn thứ nhất hàm dưới sẽ giúp các nhà lâm sàng có thêm cơ sở khi điều trị phẫu thuật nội nha cho các răng này, tránh được các sai sót khi bộc lộ và cắt bỏ 3 mm phần chóp chân răng khi phẫu thuật, giúp thủ thuật có tiên lượng tốt hơn.

Nhằm giúp các nhà lâm sàng đưa ra kế hoạch điều trị tối ưu nhất cũng như dự đoán được tiên lượng trước khi tiến hành điều trị phục hồi và bảo tồn, nhiều nghiên cứu trên thế giới đã tập trung khảo sát những đặc điểm giải phẫu vùng răng cối lớn thứ nhất hàm dưới về hình thái và số lượng chân răng với mong muốn tạo ra một bộ cở sở dữ liệu về vùng giải phẫu quan trọng này. Trong đó, nhiều nghiên cứu sử dụng phương tiện chủ yếu là Phim cắt lớp điện toán chùm tia hình nón (ConeBeam CT - CBCT). Hiện nay, đây là công cụ tốt nhất để khảo sát mô cứng vùng răng hàm mặt, theo ba chiêu trong không gian với ưu điểm cho hình ảnh rõ nét, giảm thiểu độ biến dạng và kỹ thuật hầu như là không xâm lẩn. Thông tin toàn diện về số lượng, vị trí chân răng và đặc biệt là giải phẫu hê thống ống tủy, kích thước các vách xương ổ răng, tương quan giữa các chóp răng với ống răng dưới của răng cối lớn thứ nhất hàm dưới chỉ có thể được cung cấp bởi phim CBCT. Mục tiêu của nghiên cứu là nhằm xác định các kích thước từ các vách xương vùng chóp đến các cấu trúc giải phẫu của răng cối lớn thứ nhất hàm dưới ở người Việt Nam khảo sát trên phim CBCT.

\section{II. ĐỐl TƯợNG VÀ PHƯƠNG PHÁP NGHIÊN CỨU}

2.1.Thiết kế nghiên cứu: Nghiên cứu cắt ngang mô tả

Mẫu nghiên cứu là các phim $\mathrm{CBCT}$ xương hàm dưới của các cá thể thỏa điều kiện chọn mẫu được chụp theo chỉ định của bác sĩ tại Trung tâm CT nha khoa Nguyễn Trãi - địa chỉ 132 An Bình Quận 5 - thành phố Hồ Chí Minh, trong thời gian nghiên cứu từ tháng 10/2015 đến tháng 6/2016. Dựa vào tỉ lệ răng cối lớn thứ nhất hàm dưới có ba chân ở người Thái Lan (nghiên cứu của Gulabivala và c.s. (2002), $p=0,127$, trong nghiên cứu này tính được cỡ mẫu tương ứng là $\mathrm{n}=166$. Công thức tính cõ̃ mẫu $\mathrm{n}=\left[\mathrm{Z}^{2}{ }_{1-\mathrm{a} / 2} \mathrm{p}(1-\right.$ $\mathrm{p}) / \mathrm{d}^{2}$ ] (trong đó $\mathrm{a}=0,02$ : xác suất sai lầm loại $\mathrm{I}$; $Z_{1-a / 2}=2,32$ : trị số phân phối chuẩn; $d=0,06$ : độ chính xác mong muốn). Hình ảnh $\mathrm{CBCT}$ xương hàm dưới của người Việt Nam có đủ hai răng cối lớn thứ nhất hàm dưới (răng 36 và răng 46). Phim $\mathrm{CBCT}$ được chụp bằng máy chụp phim Picasso Trio (Ewoo Vatech, Korea) với các điều kiện và tư thế chuẩn của bệnh nhân cho chụp phim (chiều dày mỗi lát cắt $0,1 \mathrm{~mm}$; FOV: $8 \times 5 \mathrm{~cm}$; thời gian chụp: 15 giây; thời gian dựng ảnh 29 giây). Răng cối lớn thứ nhất hàm dưới thỏa điều kiện: răng phát triển đầy đủ và đã đóng chóp. Các răng khảo sát không có bất thường về vị trí, không có tiêu ngót chân răng, bệnh lý nha chu, nhiễm trùng chóp ảnh hưởng đến việc đánh giá 
vách xương, ống thần kinh răng dưới; răng không có điều trị nội nha, thân và chân răng không bị các tổn thương (sâu răng, mòn răng, nứt) hay miếng trám lớn ảnh hưởng đến hốc tủy, có đầy đủ thông tin về năm sinh, giới tính, ngày chụp; phim đạt chuẩn, hình ảnh rõ nét, độ sáng đủ, độ tương phản rõ.

Hình ảnh CBCT thu thâp từ trung tâm $\mathrm{CT}$ đat tiêu chuẩn chọn mẫu được quan sát trên máy tính màn hình phẳng 14 inch, độ phân giải 1366 x 768 pixel với phần mềm EzImplant CD viewer. Quan sát trên phim và ghi nhận kết quả. Ghi nhận mã số phim, giới tính, tuổi, ngày chụp, tên bệnh nhân (viết tắt) vào phiếu thu thập. Khi tiến hành đo phần thông tin của bệnh nhân trên phim và trên phiếu thu thấp kết quả được che đi. Ghi nhận vị trí răng (răng 36 và răng 46), phim cần đo được chuyển về chế độ xem gốc ban đầu (thao tác Reset all), với độ phóng đại 1,5 lần. Trong mặt phẳng ngang (Axial) di chuyển gốc trục tọa độ đến chính giữa mỗi chân răng của răng cối lớn thứ nhất hàm dưới cần đo, đường cắt đứng dọc theo hướng ngoài - trong, chia chân răng thành hai phần tương đối bằng nhau. Trong mă̆t phẳng đứng dọc (Sagittal) điều chỉnh đường cắt đứng dọc theo trục mối chân răng cần đo. Tiến hành vẽ và đo đạc trong mặt phẳng đứng ngang (Coronal) (độ phóng đại 2 lần). Xác định các kích thước tại vị trí mổi chân răng: (1) Khoảng cách $(K C) 1$ : bề dày xương từ mặt ngoài xương hàm dưới tới chân răng cối lớn thứ nhất hàm dưới, ở vị trí cách chóp chân răng $3 \mathrm{~mm}$; (2) Khoảng cách 2: bề dày xương từ mặt trong xương hàm dưới tới chân răng cối lớn thứ nhất hàm dưới, ở vị trí cách chóp chân răng $3 \mathrm{~mm}$; (3) Khoảng cách 3: bề rộng xương hàm dưới ở vị trí cách chóp chân răng $3 \mathrm{~mm}$.
2.2. Vấn đề y đức: Nghiên cứu được thông qua bởi Hội đồng đạo đức trong nghiên cứu y sinh học ĐHYD TP. Hồ Chí Minh (tháng 10/2015).

\section{KẾT QUẢ NGHIÊN CỨU}

3.1. Đặc điểm mẫu nghiên cứu. Mẫu nghiên cứu gồm phim CBCT của 166 người, trong đó nam chiếm $56,6 \%$ và nữ chiếm $43,4 \%$ (Bảng 1). Xét theo nhóm tuổi có 83 đối tượng từ 30 - 50 tuổi, cao hơn gấp đôi so với đối tượng dưới 30 tuổi (41 người) và trên 50 tuổi (42 người).

Bảng 1. Đặc điểm mẫu nghiên cứu.

\begin{tabular}{|c|c|c|c|}
\hline \multirow{2}{*}{$\begin{array}{c}\text { Nhóm } \\
\text { tuổi }\end{array}$} & \multicolumn{3}{|c|}{ Mấu nghiên cứu (n = 166) } \\
\cline { 2 - 4 } & $\begin{array}{c}\text { Nam } \\
\mathbf{n ( \% )}\end{array}$ & $\mathbf{N u ̛ ̃} \mathbf{n ( \% )}$ & $\begin{array}{c}\text { Tống } \\
\mathbf{N}\end{array}$ \\
\hline $\begin{array}{c}\text { Từ } 18- \\
\text { dưới } 30\end{array}$ & $16(17)$ & $25(34,7)$ & 41 \\
\hline Từ $30-50$ & $42(44,7)$ & $41(56,9)$ & 83 \\
\hline Trên 50 & $36(38,3)$ & $6(8,3)$ & 42 \\
\hline Toàn mâu & 94 & 72 & 166 \\
\hline
\end{tabular}

Mỗi đối tượng trong mẫu nghiên cứu được khảo sát 2 răng cối lớn thứ nhất hàm dưới gồm răng 36 và răng 46, tổng cộng có 332 răng được nghiên cứu.

3.2. Bề dày vách xương và bề rộng xương hàm dưới tại vị trí cách chóp răng 3 $\mathbf{m m}$. Đối với các răng cối lớn thứ nhất hàm dưới có hai chân, khoảng cách từ mặt ngoài xương hàm dưới tới chóp chân gần, chân xa tại vị trí cách chóp $3 \mathrm{~mm}$ lần lượt có giá trị trung vị (GTNN - GTLN) là $2,1 \mathrm{~mm}(0,1-5,6), 2,9 \mathrm{~mm}(1,1-$ $5,2)$. Khoảng cách từ mặt trong xương hàm dưới tới chóp chân gần, chân xa tại vị trí cách chóp $3 \mathrm{~mm}$ lần lượt là $4,61 \pm 1,15 \mathrm{~mm}, 5,03 \pm 1,14 \mathrm{~mm}$. Bề rộng xương hàm dưới tại vị trí cách chóp 3 $\mathrm{mm}$ của chân gần là $12,58 \pm 1,51 \mathrm{~mm}$, của chân xa là 13,26士1,59 mm (bảng 2).

Bảng 2. Bề dày vách xương và bề rộng xương hàm dưới tại vị trí cách chóp răng $3 \mathbf{~ m m}$ của các răng côi lớn thứ nhất hàm dưới hai chân (đơn vị: mm).

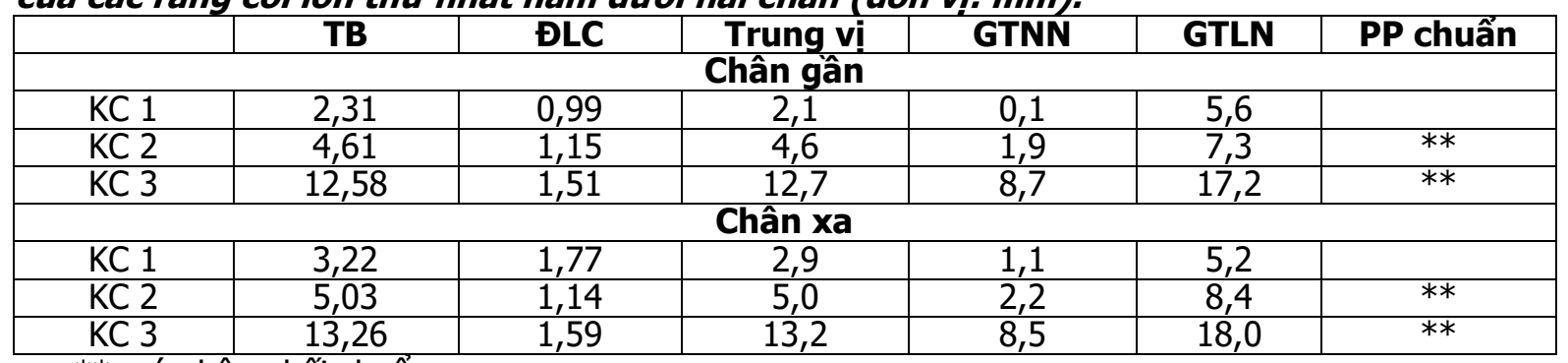

**: có phân phối chuấn

Đối với các răng cối lớn thứ nhất hàm dưới có ba chân, khoảng cách từ mă̆t ngoài xương hàm dưới tới chóp chân gần, chân xa ngoài, chân xa trong tại vị trí cách chóp $3 \mathrm{~mm}$ lần lượt là $2,41 \pm 1,09$ $\mathrm{mm}, 2,22 \pm 0,98 \mathrm{~mm}, 8,66 \pm 1,23 \mathrm{~mm}$. Khoảng cách từ mặt trong xương hàm dưới tới chóp chân gân, chân xa ngoài, chân xa trong tại vị trí cách chóp $3 \mathrm{~mm}$ lần lượt là 4,76 $\pm 1,23 \mathrm{~mm}, 7,69 \pm 1,08 \mathrm{~mm}$, $2,08 \pm \mathrm{mm}$. Bề rộng xương hàm dưới tại vị trí cách chóp $3 \mathrm{~mm}$ của chân gần, chân xa ngoài, chân xa 


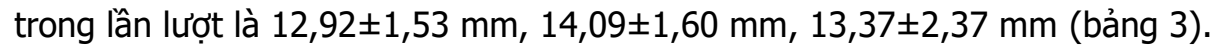

Bảng 3. Bề dày vách xương và bề rông xương hàm dưới tại vị trí cách chóp răng $3 \mathbf{m m}$ của các răng cối lớn thứ nhất hàm dưới ba chân (đớn vị: $\mathbf{m m}$ ).

\begin{tabular}{|c|c|c|c|c|c|c|}
\hline (2) & TB & ĐLC & Trung vi & GTNN & GTLN & PP chuấn \\
\hline \multicolumn{7}{|c|}{ Chân gân } \\
\hline KC 1 & 2,41 & 1,09 & 2,2 & 0,9 & 4,9 & ** \\
\hline KC 2 & 4,76 & 1,23 & 4,7 & 2,4 & 6,9 & ** \\
\hline KC 3 & 12,92 & 1,53 & 12,7 & 9,5 & 16,0 & ** \\
\hline \multicolumn{7}{|c|}{ Chân xa ngoài } \\
\hline KC 1 & 2,22 & 0,98 & 2,0 & 0,8 & 4,6 & $* *$ \\
\hline KC 2 & 7,69 & 1,08 & 7,7 & 5,2 & 9,9 & ** \\
\hline KC 3 & 14,09 & 1,60 & 14,1 & 11,3 & 17,3 & ** \\
\hline \multicolumn{7}{|c|}{ Chân xa trong } \\
\hline KC 1 & 8,66 & 1,23 & 8,5 & 6,6 & 12,1 & ** \\
\hline KC 2 & 2,08 & 0,80 & 2,0 & 0,6 & 3,9 & $* *$ \\
\hline KC 3 & 13,37 & 2,37 & 13,5 & 1,3 & 16,3 & ** \\
\hline
\end{tabular}

** Có phân phối chuấn

Bề dày vách xương và bề rộng xương hàm dưới tại vị trí cách chóp răng $3 \mathrm{~mm}$ xét theo giới được thể hiện trong bảng 4 và bảng 5 . Nhìn chung các kích thước của nam đều lớn hơn của nữ, trong đó có một vài kích thước khác biệt có ý nghĩa $(\mathrm{p}<0,05)$.

Bảng 4. Bề dày vách xương và bề rộng xương hàm dưới tại vị trí cách chóp răng $3 \mathbf{~ m m}$ của các răng cối lớn thứ nhất hàm dưới hai chân theo giới (đ̛ớn vị: mm).

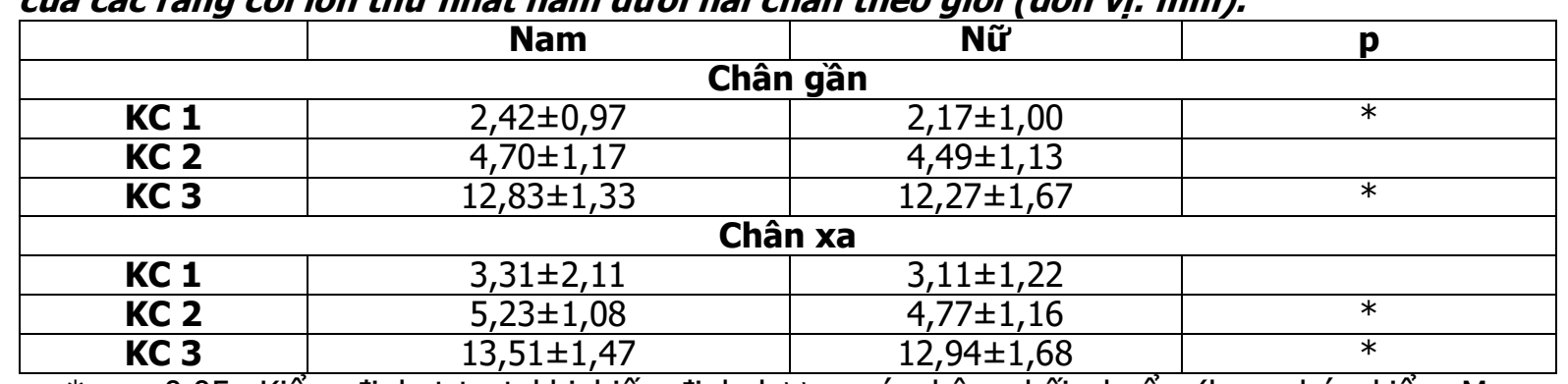

*p < 0,05; Kiểm đinh t-test khi biến đinh lượng có phân phối chuẩn (hay phép kiểm MannWhitney khi biến định lượng có phân phối không chuẩn).

Bảng 5. Bề dày vách xương và bề rông xương hàm dưới tại vị trí cách chóp răng $3 \mathbf{m m}$ của các răng cối lớn thứ nhât hàm dưới ba chân theo giới (đớn vị: mm).

\begin{tabular}{|l|r|r|r|}
\hline \multicolumn{5}{|c|}{ Nam } & Nữ & P \\
\hline \multicolumn{5}{|c|}{ Chân gân } \\
\hline KC 2 & $2,62 \pm 1,09$ & $2,04 \pm 1,02$ & \\
\hline KC 3 & $4,75 \pm 1,38$ & $4,77 \pm 0,99$ & \\
\hline \multicolumn{5}{|c|}{ Chân xa ngoài } \\
\hline KC 1 & $13,10 \pm 1,62,61 \pm 1,37$ & \\
\hline KC 2 & $2,34 \pm 0,93$ & $2,01 \pm 1,07$ & \\
\hline KC 3 & $7,89 \pm 1,03$ & $7,35 \pm 1,12$ & \\
\hline \multicolumn{5}{|c|}{ Chân xa trong } \\
\hline KC 1 & $14,41 \pm 1,61$ & $8,69 \pm 0,88$ & \\
\hline KC 2 & $8,64 \pm 1,41$ & $1,83 \pm 0,77$ & $*$ \\
\hline KC 3 & $2,22 \pm 0,79$ & $12,42 \pm 3,29$ & \\
\hline
\end{tabular}

*: $\mathrm{p}<0,05$; Kiểm định t-test khi biến định lượng có phân phối chuẩn (hay phép kiểm MannWhitney khi biến định lượng có phân phối không chuẩn).

Bề dày vách xương và bề rộng xương hàm dưới tại vị trí cách chóp răng $3 \mathrm{~mm}$ xét theo nhóm tuổi được thể hiện trong bảng 6 . Các khoảng cách đo được trong nghiên cứu đều không khác biệt giữa các nhóm tuổi $(p>0,05)$. 
Bảng 6. Bề dày vách xương và bề rộng xương hàm dưới tại vị trí cách chóp răng $3 \mathrm{~mm}$ của các răng cối lớn thứ nhất hàm dưới hai chân theo nhóm tuổi (đớn vị: $\mathrm{mm}$ ).

\begin{tabular}{|c|c|c|c|c|}
\hline & $<\mathbf{3 0}$ & $\mathbf{3 0 - 5 0}$ & $\mathbf{> 5 0}$ & $\mathbf{p}$ \\
\hline Chân gần & & & & \\
\hline KC 1 & $2,39 \pm 1,16$ & $2,27 \pm 1,00$ & $2,29 \pm 0,76$ & \\
\hline KC 2 & $4,49 \pm 1,21$ & $4,56 \pm 1,13$ & $4,83 \pm 1,13$ & \\
\hline KC 3 & $12,50 \pm 1,67$ & $12,54 \pm 1,56$ & $12,77 \pm 1,22$ & \\
\hline Chân xa & & & & \\
\hline KC 1 & $3,35 \pm 1,47$ & $3,13 \pm 1,13$ & $3,28 \pm 2,85$ & \\
\hline KC 2 & $4,94 \pm 1,17$ & $4,96 \pm 1,18$ & $5,26 \pm 1,00$ & \\
\hline KC 3 & $13,47 \pm 1,66$ & $13,18 \pm 1,65$ & $13,18 \pm 1,35$ & \\
\hline
\end{tabular}

Kiếm định ANOVA khi biến định lượng có phân phối chuấn (hay phép kiếm Kruskal -Wallis khi biến định lượng có phân phối không chuẩn).

Các giá trị p trong bảng này đều lớn hơn 0,05

\section{BÀN LUÂNN}

Nghiên cứu được thực hiện trên dữ liệu phim CBCT của 166 người trong kho phim CBCT lưu trữ tại trung tâm CT Nguyễn Trãi. Trong 166 người đưa vào nghiên cứu, có 94 nam và 72 nũ̃, tỉ lệ nam : nữ tương đương 3:2. Xét sự phân bố theo tuổi, $50 \%$ số cá thể trong mẫu nghiên cứu thuộc nhóm tuổi từ 30 đến 50 . Các cá thể còn lại phân bố khá đồng đều vào hai nhóm tuổi còn lại (41 người dưới 30 tuổi và 42 người trên 50 tuổi). Sự phân bố không đều do tiêu chuẩn chọn mẫu yểu cầu bệnh nhân có nguyên vẹn hai răng cối lớn thứ nhất hàm dưới, không có phục hồi, miếng trám, điều trị tủy và không có bệnh lý nha chu nghiêm trọng trong khi đó răng cối lớn nhất hàm dưới lại là răng có tỉ lệ sâu mất trám cao nhất kể cả các lứa tuổi. Sự không tương đồng về giới tính và tuổi của mấu nghiên cứu làm cho việc so sánh giữa các nhóm không thuận lợi.

Việc chia mẫu nghiên cứu thành ba nhóm tuổi như trên là phù hợp với từng giai đoạn phát triển hê xương của cơ thể và do đó phù hợp để khảo sát bề dày vách xương và bề rộng xương hàm dưới tại vị trí cách chóp chân răng $3 \mathrm{~mm}$ của răng cối lớn thứ nhất hàm dưới của các cá thể.

Trên thế giới có hai nguồn tư liệu thường được sử dụng để nghiên cứu vị trí các cấu trúc giải phẫu trong xương là đo đạc trực tiếp trên xương khô hay trên xác và đo đạc gián tiếp qua các hình ảnh chụp từ các phương tiện chẩn đoán hình ảnh ba chiều hiện nay như CT hay CBCT. Những nghiên cứu trển xương khô hay trên xác tuy là xem trực tiếp nhưng bi hạn chế về số lượng và chất lượng mấu cũng như thất lạc thồng tin của bệnh nhân nên không phân tích được sự liên quan vị trí, kích thước của các cấu trúc giải phẫu với tuổi và giới tính.

Kết hợp các bằng chứng khoa học đã có với mục tiêu nghiên cứu cũng như điều kiện nghiên cứu hiện tại, chúng tôi nhận thây $\mathrm{CBCT}$ là phương tiện tối ưu và hữu ích nhất giúp nghiên cứu và khảo sát toàn diện, đồng thời các đặc điểm giải phẫu của chân rắng cối lớn thứ nhất hàm dưới bao gồm số lượng, vị trí chân răng, giải phẫu hê thống ống tủy, bề dày vách xương tại vị trí chóp răng, tương quan giữa các chóp rằng với ống răng dưới ở người Việt. Dữ liệu $\mathrm{CBCT}$ được lưu trữ khá dồi dào, hình ảnh rõ ràng, có ghi nhận họ tên, giới tính, ngày tháng năm sinh, ngày chụp giúp chúng tôi xác định được giới tính và tuổi của các cá thể tại thời điểm chụp. Các nghiên cứu trước đây thường chọn nguiôn phim lưu trữ sẵn. Điều này rất thuận tiện để nghiên cứu một cõ̃ mẫu lớn trong một thời gian ngắn. Đây là thuân lợi của phương pháp nghiên cứu sử dụng dữ liệu chẩn đoán hình ảnh săn có.

Trong nghiên cứu này, đối với các RCL thứ nhất hàm dưới có hai chân, chúng tôi ghi nhận được khoảng cách từ mă̆t ngoài XHD đến chóp chân gần và chân xa tại vị trí cách chóp $3 \mathrm{~mm}$ lần lượt là $2,31 \pm 0,99 \mathrm{~mm}, 3,22 \pm 1,77 \mathrm{~mm}$. Đối với các RCL thứ nhất hàm dưới có ba chân, khoảng cách từ mă̆t ngoài XHD đến chóp chân gần và chân xa ngoài và chân xa trong tại vị trí cách chóp $3 \mathrm{~mm}$ lần lượt là $2,41 \pm 1,09$ mm, 2,22 00,98 $\mathrm{mm}, 8,66 \pm 1,23 \mathrm{~mm}$. Bề rộng xương hàm dưới theo chiều ngoài trong ở mức cách chóp răng $3 \mathrm{~mm}$ nhỏ hơn ở nữ so với nam $(p<0,01)$. Bề rộng xương hàm dưới ở mức ngang ống răng dưới thì không có sự khác biệt giữa nam và nữ.

Kỹ thuật chụp phim quanh chóp thông thường chỉ cung cấp hình ảnh hai chiều và phim bị nhiếu nếu răng kế cận có mão răng, miếng trám, đặt chốt hoặc đặt implant. Vì vậy phim $\mathrm{CBCT}$ có thể được chỉ định trong trường hợp tìm thấy bất thường trên phim quanh chóp hoặc nhà lâm sàng nghi ngờ hệ thống ống tủy phức tạp hơn bình thường. Uu điểm của CBCT là không xâm lấn, cho hình ảnh ba chiều, quan sát được 
giải phẫu bên trong và bên ngoài của răng.

Để đánh giá độ tin cậy của nghiên cứu, chúng tôi chọn ngẩu nhiên 33 phim không phân biệt nam nữ, tuổi tác và đo lại sau 2 tuần. Hệ số tương quan nội lớp (ICC- intraclass correlation coefficients) được tính để đánh giá độ tin cậy của các biến định lượng giữa hai lần đo. Hệ số tương quan giữa 2 lần đo trên 0,8 cho thây phương pháp đo có độ tin cậy cao.

\section{KẾT LUÂN}

Chóp các chân răng của RCL thứ nhất hàm dưới nằm rất gần mặt ngoài xương hàm dưới, lưu ý các bác sĩ phẫu thuật nôi nha cẩn trong trong các thủ thuật điều trị phẩu thuật nội nha cho các răng này.

\section{TÀI LIÊU THAM KHẢO}

1. Nguyễn Cẩn, Ngô Đồng Khanh. (2007), "Phân tích dich tễ bếnh sâu răng và nha chu ở Viết Nam". Tạp chí Y học Thành phố Hồ Chí Minh, 11(3), 144-149.
2. de Pablo O. V., Estevez R., Peix Sanchez M., et al. (2010), "Root anatomy and canal configuration of the permanent mandibular first molar: a systematic review". J Endod, 36(12), 1919-1931.

3. Chen Y. C., Lee Y. Y., Pai S. F., et al. (2009), "The morphologic characteristics of the distolingual roots of mandibular first molars in a Taiwanese population". J Endod, 35(5), 643-645.

4. Curzon M. E. ,Curzon J. A. (1971), "Threerooted mandibular molars in the Keewatin Eskimo". J Can Dent Assoc (Tor), 37(2), 71-72.

5. Curzon M. E. (1974), "Miscegenation and the prevalence of three-rooted mandibular first molars in the Baffin Eskimo". Community Dent Oral Epidemiol, 2(3), 130-131.

6. de Souza-Freitas J. A., Lopes E. S. ,CasatiAlvares L. (1971), "Anatomic variations of lower first permanent molar roots in two ethnic groups". Oral Surg Oral Med Oral Pathol, 31(2), 274-278.

7. Tratman E. K. (1938), "Three rooted lower molars in man and their racial distribution". Bristish Dental Journal, 64, 264-274.

8. Gulabivala K., Opasanon A., Ng Y. L., et al. (2002), "Root and canal morphology of Thai mandibular molars". Int Endod J, 35(1), 56-62.

\title{
LIÊN QUAN GIỮA RỐI LOAN NHIỄM SẮC THỂ Ở PHÔI NGÀY 5 VỚI TUỔI ME TRONG THỤ TINH TRONG ỐNG NGHIỆM
}

\author{
${ }^{1}$ Nguyễn Thị Bích Vân, ${ }^{2}$ Nguyễn Duy Bắc, ${ }^{1}$ Nguyễn Viết Tiến \\ ${ }^{2}$ Đặng Tiến Trường, ${ }^{3}$ Lê Hoàng
}

\section{TÓM TẮT}

Mục tiêu: Nghiên cứu thực hiện trên 60 cặp vợ chồng vô sinh thực hiện thư tinh trong ống nghiệm (IVF) có phôi ngày 5 được giải trình tự gen thế hệ mới (NGS) nhằm phân tích mối liên quan giữa rối loạn nhiễm sắc thể (NST) ở phôi ngày 5 với tuổi của me. Phương pháp: Nghiện cứu mô tả cắt ngang. Kểt quả: Phôi lệch bôi nhiễm sắc thể ở nhóm tuổi của me dưới 35 là 36,28\%, ở nhóm tuổi me 35-39 là 49,1\% và nhóm tuổi me trên 40 tuổi là $54,0 \%$. Nghiên cứu này không có sự khác biệt về loại lệch bội nhiễm sắc thể ở các nhóm tuổi khác nhau. Kết quả cũng cho thấy, cứ $22,87 \%$ sự biến đổi của tỷ lệ rối loạn số lương NST được giải thích bởi sự biến đổi của yếu tố tuổi mẹ (hệ sổ xác định R-square $=0,2287$ ). Khi tuổi me tăng thềm 1 đơn vị thì tỷ lệ rối loạn số lượng NST sẽ tăng thêm 0,01 đơn vị. Kết luâan: Có sự liên quan của tuổi người mẹ với lệch bội nhiểm sắc thể. Tuổi của mẹ tăng làm tăng tỷ lệ rối loạn số lượng NST.

\footnotetext{
1 Trường Đai hoc Y Hà Nọi

${ }^{2} H o$ oc viện Quần $Y$

${ }^{3}$ Bềnh viên Đa khoa Tâm Anh

Chịu trách nhiệm chính: Nguyễn Thị Bích Vân

Email: vannhim72@gmail.com

Ngày nhận bài: 11/9/2021

Ngày phản biên khoa hoc: $5 / 10 / 2021$

Ngày duyệt bài: 19/10/2021
}

Tư khóa: rối loạn nhiễm sắc thể, phôi 5 ngày, tuổi mẹ, thụ tinh trong ống nghiệm, giải trình tự gen thế hệ mới.

\section{SUMMARY \\ CHROMOSOMAL DISORDERS OF EMBRYOS IN THE 5TH DAY WITH MOTHER'S AGE IN IN-VITRO FERTILIZATION}

Objectives: The study performed on 60 infertile couples performing in vitro fertilization who have embryos of the 5th day with Next Generation Sequencing (NGS) in order to analyze the relationship between chromosomal disorders (chromosome) of embryos in the 5th day with mother's age. Method: Cross sectional study. Results: The chromosomal aneuploidy embryo in the maternal age group under 35 was $36.28 \%$, the maternal age group $35-39$ was $49.1 \%$ and the maternal age group over 40 years old was $54.0 \%$. This study did not differ in type of chromosomal aneuploidy in different age groups. The results also show that, for every $22.87 \%$, the change in the rate of chromosomal number disorders is explained by the variation of the maternal age factor (R-square determination coefficient $=0.22287$ ). When the mother's age increases by 1 unit, the rate of chromosomal disorders will increase by 0.01 units. Conclusion: There is an association of maternal age with chromosomal aneuploidy. Increasing mother's age increases the incidence of chromosomal disorders 